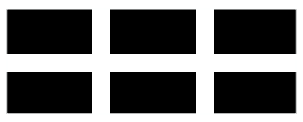

THE WILLIAM DAVIDSON INSTITUTE AT THE UNIVERSITY OF MICHIGAN BUSINESS SCHOOL

\title{
Russian Cities in Transition: The Impact Of Market Forces in the 1990s
}

\author{
By: Ira N. Gang and Robert C. Stuart
}

William Davidson Institute Working Paper Number 697

May 2004 


\title{
Russian Cities in Transition: The Impact of Market Forces in the 1990s
}

\author{
by \\ Ira N. Gang \\ Department of Economics \\ Rutgers University \\ 75 Hamilton Street \\ New Brunswick, N.J. 08901-1248 \\ Phone: (732)932-7405 Fax: (732) 932-7416 \\ e-mail: gang@economics.rutgers.edu \\ and \\ Robert C. Stuart \\ Department of Economics \\ Rutgers University \\ 75 Hamilton Street \\ New Brunswick, N.J. 08901-1248 \\ Phone: (732) 932-8841 Fax: (732) 932-7416 \\ e-mail: stuart@economics.rutgers.edu
}

Second Revised Draft: May 2004

\begin{abstract}
This paper analyses Russian city growth during the command and transition eras. Our main focus is on understanding the extent to which market forces are replacing command forces, and the resulting changes in Russian city growth patterns. We examine net migration rates for a sample of 171 medium and large cities for the period 1960 through 2002. We conclude that while the declining net migration rate was reversed during the first half of the 1990s, restrictions continued to matter during the early years of transition in the sense that net migration rates were lower in the restricted than in the unrestricted cities. This pattern seemingly came to an end in the late 1990s.
\end{abstract}

Keyword(s): cities; city growth; migration; Russia; urbanization JEL Code(s): J6; P20; R23

We thank the Research Council of Rutgers University, and the Program in Urbanization and Migration, Office of Population Research, Princeton University for financial support. We thank Iryna Kosse for excellent research assistance. Responsibility for the content of this paper rests with the authors. 


\section{Russian Cities in Transition: The Impact of Market Forces in the 1990s}

\section{I: Introduction}

The subject of Russian urban expansion, and specifically the growth patterns of Russian cities, has been of great interest to economists and indeed to a wide spectrum of researchers. While much of our general understanding of city growth patterns emerges from the study of market economies, a contrasting body of knowledge on city growth emerges from our interest in the formerly centrally planned economies (CPE's). Of special interest in this context is the nature and extent that city growth patterns in CPE's have differed from patterns observed in market economies, these differences driven by very different economic systems, policies and environmental (natural) factors. To this line of inquiry we can now add a new and important dimension since market forces have replaced the majority of the command arrangements. What patterns of change can be observed in urban Russia since the collapse of the command order and its replacement with market forces?

In this paper our central focus is the extent to which Soviet era aberrations (non-market outcomes observed in city growth patterns) remain in Russia during the transition era of the 1990s. ${ }^{1}$ Specifically, to the extent that controls placed upon urban expansion were effective during the command era, were these controls still pervasive during the transition era of the 1990s and thereafter? We are also concerned with the extent to which contemporary theorizing about city growth in market settings can be helpful for our continuing understanding of the contemporary Russian (market) setting.

This paper is divided into five parts. In part II we provide a summary of Soviet (command era) city growth patterns for Russia. In Section III we examine issues pertaining to Russian city growth in the transition era, and introduce the data that will be used in this study. In Section IV we present and summarize our findings and, finally, in Section V we present our conclusions and suggestions for further research.

${ }^{1}$ While earlier works have focused on the Soviet Union, this study focuses on Russia. The Russian Federation was formed by the separation of Russia from the Soviet Union on August 24, 1991 and has been accompanied by the replacement of the command system by market arrangements based upon private property rights. 


\section{II: City Growth: Russia Under Systemic Change}

Urban (city) growth in the formerly centrally planned economies (CPE's) is the subject of a large literature. As with other aspects of economic development in the CPE's, there has also been a great deal of interest in comparing urban development patterns in the CPE's to urban development patterns in market economic systems. Obviously these comparisons are of interest for understanding the emergence of markets in the former CPE's and the impact of newly emerging market arrangements on urbanization patterns. Comparisons of urban (city) growth across differing economic systems have been difficult for at least two important reasons. First, it was difficult to understand and to model the relationship between urban (city) growth and the peculiar institutional arrangements and differing policy imperatives in the CPE's. State control and ownership in a socialist policy framework enabled the state to control almost all facets of the urban setting. In a sense, the difficulties of understanding these relationships in market economies were multiplied for the case of CPE's. Second, the absence of data, especially microeconomic data for the CPEs, further complicated efforts to model and analyze the forces underlying urban (city) growth. To some degree, these difficulties have become more tractable during the transition era, making command/transition comparisons possible.

Over many years during the command era, the growth of Russian cities was a function of several identifiable and interrelated forces. The Soviet economic (command) system, especially the absence of private property rights and the presence of an integrated hierarchical decision making system, influenced the nature of Russian cities. These organizational or systemic arrangements facilitated the implementation of an urban policy agenda very different from that typically found in Western market economies. Soviet leaders developed and implemented a set of urban policies differing from those typically found in market settings. For example, the concept of a "socialist city" influenced many features of cities, such as size distribution, location and economic functions. Although it was difficult to model Russian city growth using traditional market models, nevertheless socialist differences could generally be understood. Indeed, general patterns of urban growth in the command setting have been studied in some depth (Harris 1972, Ofer 1971, Lewis and Rowland 1979) with general outcomes surveyed (Bater 1980, Morton and Stuart 1984).

Migration, an important component of urban growth, has been studied (Stuart and Gregory 1979, Grandstaff 1980) and the resulting size distribution of cities examined (Clayton 
and Richardson 1989). Recently, this earlier discussion has been extended (Mitchnek 1990, Buckley 1995) with the issue of socialist controls (especially city residence permits) being of central focus. These controls have been analyzed in some depth (Gang and Stuart 1999, 2002) and have been found to exert considerable influence over city growth during the plan era. Previous studies have found that under appropriate controls for important variables such as city size, cities whose rates of growth were in some manner controlled (typically through the propiska or residence permit requirement), experienced growth rates were lower than would otherwise have been expected.

To the extent that the command system has been replaced, at least to a degree, by private property and market arrangements and related market-type policies, a question of central importance in contemporary Russia (and indeed in other transition settings) is the nature of city growth in a new and very different setting. The economic system has changed, and in varying degrees, the policy agenda has also changed.

During the transition era of the 1990s, population issues have been on center stage in the discussion of Russia and other transition economies. The main centers of controversy in the Russian case have been population growth and to a lesser degree population mobility. The controversy surrounding population growth in Russia has focused on declines in birth rates, increases in death rates and the resulting decline in the rate of growth of the Russian population. Whether these observed trends represent short-term abnormalities or longer-term convergence towards market patterns remains a matter of discussion. ${ }^{2}$

The attention paid to population mobility has been less intense and perhaps less controversial, although there seems to be a perception in the West that Russian population mobility during transition has been rather high, perhaps based in part upon an observed exodus from areas such as Siberia to areas in the West and South, the latter more habitable economically and more viable under market forces, the former no longer receiving significant subsidies for space and the military. Empirical evidence (Andrienko and Guriev 2003) seems to suggest that migration rates are not in fact high, and can be largely explained by traditional factors, although

\footnotetext{
${ }^{2}$ Brainerd and Varavikova (2003).
} 
there has been some change of regional migration patterns in the past few years. Nevertheless, the subject has attracted considerable attention (Gerber 2000, Heleniak 2002). ${ }^{3}$

We turn to an examination of the growth of Russian cities during the transition era of the 1990s comparing these contemporary migration patterns to those established earlier during the command era. Our focus is the extent to which observed patterns of growth analyzed for the plan era have in fact changed during transition.

\section{III: Russian City Growth: From Command to Demand}

\section{A. Data and Methods}

This paper builds upon previous published work devoted to the growth of Soviet and Russian cities (Gang and Stuart 1999, 2002). We use a database of 171 cities located in 71 oblasts (provinces) of Russia. We examine patterns of urban growth in Russia from 1960 (a convenient starting date since there was a census in 1959) through 2002, the most recent census for which some results are now available. Our sample consists of those cities with a population of 50,000 or more as of the census of 1959. Details of our data construction are in the Appendix.

During this period, the population of Russia grew at an average annual rate of 1.21 percent. The urban population grew at an average annual rate of 3.25 percent while the rural population declined at an average annual rate of 1.97 percent. Thus while the urban-rural population balance was roughly $52 / 48$ percent in the census of 1959 , it was roughly $73 / 27$ percent in the census of 2002.

Our focus is the net migration rate (NMR) into cities, some under the influence of controls and others not controlled. The NMR is defined as arrivals into each city less departures from each city. It is the population growth rate of each city adjusted for the net internal expansion of each city (births minus deaths). We do not adjust for administrative reclassification during this period since most such re-classification concerned the creations of cities (gorod) from villages of a city type (poselki gorodskogo tipa) and did not result in an expansion

\footnotetext{
${ }^{3}$ Renewed interest in Russian regions is based upon two important considerations. First, as a federation, there are emerging, changing and important distinctions among the regions. Second, major distortions in the allocation of resources established during the Soviet era will be gradually eroded by the development of market mechanisms and policies. This erosion is already evident in the movement of population away from areas formerly devoted to the military.
} 
of cities that would be relevant to our sample, namely those with a population over 50,000 in 1959.4

For the period under study, we are interested in identifying cities that are closed, an issue that requires additional discussion.

\section{B. The Issue of Closed Cities}

A crucial element for analysis of city growth has been the ability to identify closed cities (Gang and Stuart, 1999, 2002). The task of identifying restrictions on city expansion is difficult. See (Lewis and Rowland 1979, Buckley 1995, Gang and Stuart 1999, 2002). There have been two types of administrative restrictions, total restriction and expansion restriction. A total restriction meant that, in effect, the city was closed, and documents (a propiska) would be required for residence in the city. An expansion restriction (Buckley 1995) referred to limitations of an economic nature, on the extent to which investment expansion (investment to expand an industry) would be permitted. Of the 171 cities in our sample, we identify 46 as having some form of restrictions. Although there were some restrictions introduced in the $1930 \mathrm{~s}$, most were implemented during the 1950 s.

How important are these restrictions in our sample? In Table 1 we provide a basic picture of the Russian population for the period 1960 through 2001. Clearly the restricted cities in our sample have grown slower than the unrestricted cities. Almost $43 \%$ of the urban population in 1960 lived in restricted cities, a proportion which remains high at almost 40 percent in 2001. As a percent of total population, the share living in restricted cities increased from 23 percent in 1960 to 29 percent in 2001.

In Table 2 we provide additional details on our sample. For the 46 restricted cities, there is considerable variation in the incidence of restrictions by geographic regions. This variation in large part reflects the differences in the regions themselves, and as we have emphasized, is an important component of the regional re-distribution of the Russian population occurring during the 1990s. Those regions with lower levels of urbanization have fewer medium and large cities

\footnotetext{
${ }^{4}$ During the early Soviet period, there was a considerable amount of re-classification. Note that unlike Western urban settings where there are a variety of definitions (towns, villages, boroughs etc), in the Russian setting there are villages, villages of a city type (poselki gorodskogo tipa) and cities (gorod), the latter having a population of 50,000 or larger. Recent re-classification is discussed in "Ob itogakh Vserossiiskoi perepisi naseleniia 2002 goda" (About the results of the All-Russian census of the population of 2002). http://www.eastview.com/census 2002/report.pdf
} 
and hence fewer occurrences of restrictions. How important is city size to explain the incidence of restrictions, and to what degree has this pattern changed over time?

In Table 3 we examine the incidence of restrictions by city size over time. The changing size structure of restrictions is interesting but perhaps the changes that we observe are not dramatic. The incidence of a total restriction has decreased significantly in the generally smaller cities while the number of totally restricted large cities has increased. The pattern is similar for medium sized cities but with lesser degree of change. Finally, the incidence of "never restricted" has decreased for smaller cities, but has increased for larger cities. Note that the number of restricted cities is not changing, so these changes result from changes in city size, for those cities in our sample.

The problem for our analysis in this paper is understanding the changes in city growth that have taken place from the command era into and through the transition era. Indeed, our central focus is on looking for structural shifts in urbanization (city growth) patterns between the two very different periods. Since the collapse of the USSR in 1991, information has become increasingly available, a fact that has increased the amount of scrutiny placed upon mobility restrictions in the Russian Federation. A major and growing focus of concern, since the collapse of the Soviet Union, has been the secret cities involved in nuclear and related research activities. In much of the literature on the transition era of the $1990 \mathrm{~s}$, discussion of "closed cities" refers to those cities where there are nuclear or secret research facilities. There are two issues of concern, first the extent to which these nuclear cities overlap with our sample, and second, the extent to which restrictions that we identify are in fact functional during the transition era. In some respects, this latter issue is now no different from its nature in the past. As noted earlier, many have argued that during the Soviet era, there were restrictions, but people ignored them, or were able to circumvent them, so that in the end they did not "matter" in the sense that closed cities in fact continued to grow. However, it has been argued (Gang and Stuart 1999, 2001) that the restrictions did "matter", these conclusions based upon statistical analysis. These analyses suggest that while restricted cities did indeed grow, they grew less rapidly than would have been the case (controlling for city size and other factors) absent restrictions. As we attempt to unravel the transition era, there is bad news and there is good news.

The bad news is the fact that it is difficult to know exactly which cities that were closed in the Soviet era actually remain closed in the same sense and degree that they were closed 
during the Soviet era subject to total or expansion restrictions. Although conditions are in some respects quite different among the emergent self-governing regions of Russia, many would argue that restrictions have generally been maintained.

The good news is the emergence of a significant debate about the closed nuclear cities, and hence an emerging body if literature on these cities. This debate and the data available are both relevant to the present study insofar as some of these closed nuclear cities are in our sample. What is the nature of these cities and to what degree are they in our sample?

The closed nuclear cities are identified by the acronym ZATO (zakrytye administrativnoterritorial'nye obrazovaniia or closed administrative-territorial formations). These cities, some with nuclear facilities and others with secret research facilities, were established largely during the Stalin era of the 1930s (Global Security 2004). However, for a variety of obvious reasons, they are of concern in the contemporary era, especially since they have apparently been expanded during the 1990s now encompassing roughly 2 million people (Szabo 2001) and widely dispersed throughout Russia with significant financial support from the center in Moscow (Brock 2002).

Although estimates of the total number of the ZATO facilities vary, one source identifies a total of 40 such cities, approximately 17 of which are cities (gorod) with populations said to be over 20,000 (Global Security 2004). Since we examine cities (gorod) with a population over 50,000 in 1959 , the base year for our contemporary database, this potentially limits the number of such cities in our sample. In fact, a comparison of known ZATO cities and our database suggests that none of the ZATO cities are likely to be in our sample. ${ }^{5}$

\footnotetext{
${ }^{5}$ These cities were often given both local and more general names. For example, many have been identified in terms of their distance from a nearby city. So, Moscow-300 would be a secret city 300 kilometers from Moscow. In terms of population, Moscow would be in our sample, while Moscow-300 would not be in our sample. While none of the cities in our sample are "secret cities" per se, the following cities in our sample have secret cities located nearby: Arzamas, Chelyabinsk, Chita, Krasnoyarsk, Moscow, Murmansk, Nizhny Tagil, Penza, Perm, Petropavlovsk-Kamchatskiy, Sverdlovsk (Yekaterinburg), Tomsk, Zagorsk (Sergiev Posad), Zlatoust. See Murray Feshbach, Ecological Disaster: Cleaning Up the Hidden Legacy of the Soviet Regime (New York: Twentieth Century Fund, 1995), Appendix A; "Secret Cities" http://www.globalsecurity.org/wmd/world/russia/secret-cities.htm; Valentin Tikhonov, Russia's Nuclear and Missile Complex: The Human Factor (Washington, D.C.: The Carnegie Endowment for International Peace, 2001); Richard H. Rowland, "Secret Cities of Russia and Kazakhstan in 1998” Post-Soviet Geography and Economics vol. XXXX, no. 4 (June, 1999), 281-304.
} 


\section{IV: City Expansion: Data and Analysis}

\section{A. An Examination of the Data}

In Table 4 below, we present descriptive statistics to on NMR for selected years from 1960 to 2000. These results are quite striking in several dimensions. First, as the level of urbanization rises, we would expect the rate at which it occurs to decline. The decline in NMR from 2.21 in 1965 (weighted by city size) to .57 in 1999 and .30 in 2000 represents an important reduction in the rate of city growth from migration. This general pattern pertains for all city sizes and for all forms of restrictions and function.

Second, in all periods, except for 2000-2002, the NMR for unrestricted cities was larger than for restricted. Significantly, however, the magnitude of the gap, that is the gap between NMR in restricted and unrestricted cities, declined noticeably toward the end of the Soviet era, and while it remained through the mid 1990s, our evidence suggests that it was largely eliminated by the end of the first decade of transition. We present this evidence graphically in Figure 1.

What has happened to NMR in the major regions of Russia? In Table 5 we present NMR by regions of Russia. The patterns observed here are familiar, reflecting a declining NMR. There is, however, an important distinction. The pattern of decline of NMR reflects important regional differences (see Figure II) notably the decling relative attractiveness of regions such as Siberia (Andrienko and Guriev 2003). These patterns have changed somewhat after the year 2000.

\section{B. The Analysis Extended}

Thus far we have examined the trends in NMR using descriptive statistics for restricted and unrestricted cities. We now turn to a multivariate analysis to better understand the importance of differing restrictions. In Table 6, we present our OLS results.

In this analysis, the dependent variable is the NMR (as defined earlier) for the 171 cities in our sample. Our explanatory variables are population and population squared, the urban share, whether the city was the capital of its oblast, and the incidence of restrictions, that is an expansion restriction or a total restriction. In Table 5 we present the results of our statistical analysis.

These results conform quite closely to the results found in Gang and Stuart (2002). During the 1970s, for the most part, judged statistically, restrictions did not matter. During the 
1980s, restrictions did matter, though again in the 1990s, they did not matter. How do we explain these patterns, especially given the evidence presented in Figure 1 ?

First, the evidence presented in Figure 1 suggests that throughout the period under study restricted cities had lower NMRs than unrestricted cities, though seemingly to a lesser degree over time. The changing role of restrictions exhibited here is consistent with what we know about the extent of liberalization (relaxation of controls and movement toward market arrangements) during the latter years of the Soviet era and the first decade of transition.

Second, how can we explain the importance of controls in the 1980s, a decade during which Soviet society seemingly became more relaxed, especially under the leadership of Mikhail Gorbachev during the latter part of this decade? It could be that less controlled cities, receiving additional resources (especially investment) during the 1970s became more attractive during the 1980s, migration shifting from controlled to non-controlled cities independent of the controls themselves. In effect, this represents a lag not incorporated into our analysis. However, it could also be that the 1980s was a decade anticipating fiscal decentralization, an era in which local authorities increasingly became aware of the potential gains to be made through the use of local controls, a component of fiscal bargaining with the central government. There may have been liberalization at higher levels, but continuing use of controls at local levels.

Changes in the 1990s are fascinating though perhaps a longer span of years will be necessary to fully comprehend and to analyze the changes taking place during transition. Clearly cities became more attractive during the 1990s, perhaps a result of pent up demand for urban living (or mobility generally), or perhaps changes associated with the major uncertainties of the newly emerging transition era. The NMR increased during the first five years of transition, after a long and steady decline. Perhaps most striking, while restricted cities seemingly grew more slowly (controlling for city size) during the 1990s, the earlier decline of the NMR reoccurred during the latter half of the 1990s, with the apparent convergence of the NMR in the three types of cities examined in this study. It is apparent that there has been an important structural shift in urbanization (city growth) patterns between the command era and the transition era of the 1990s. 


\section{V: Conclusions}

In this paper we have examined the net migration rate (NMR) for a sample of 171 medium and large Russian cities, from 1960 through 2002. Our central focus has been the impact of restrictions on city growth, and most importantly, potential changes in the impact of those restrictions during a period of critical systemic change, namely transition.

It is important to appreciate the fact that Russia experienced fundamental systemic and policy changes after the collapse of the command era, such that we might expect, at least in theory, basic changes in the patterns of population mobility. Since freedom of mobility is guaranteed by the constitution of Russia (after 1991), and since such freedoms were totally absent during the Soviet era, would we not expect significant changes in population mobility during transition?

Since the 1960s, the movement into medium and large cities (NMR in our study) has declined in ways that we would expect. But, of great significance is the fact that while the NMR for restricted cities has always been less than that for uncontrolled cities, seemingly the gap has completely closed in the late 1990s, a critical convergence. Statistical evidence suggests that while the difference between restricted and unrestricted cities was significant in the 1980s, it was not significant in the 1970s or the 1990s.

Perhaps most important, after a brief reversal of NMR in the early years of transition, pre-transition patterns of the decline of NMR reappeared after 1995, and by the end of the decade, convergence had occurred between the restricted and unrestricted cities, although it is too early to predict if shifts observed after 2000 will persist.

The overwhelming picture from our tables, figures, and analyses is that net migration into cities has declined over the 1960-2000 time period. Moreover, the gap between the NMRs of unrestricted and restricted cities slowly closed over this period, even correcting for city size and other variables, so that by 2000, they are not distinguishable. Although we have presented census data for 2002 indicating some emerging changes, it is too early to predict to what extent these changes will be sustained in future years. 


\section{References}

Andrienko, Yuri and Sergei Guriev (2003) "Determinants of interregional mobility in Russia: evidence from panel data" Moscow: Center for Economic and Financial Research, February 2003.

Bater, James H., (1980) The Soviet City (London: E. Arnold).

Brainerd, Elizabeth and Elena Varavikova, (2003) "Death and the Market," mimeo, Williams College, Sept. 2003.

Brock, Gregory (2002) "Public Finance in the Closed Cities of Russia," http://cns.miis.edu/cns/projects/nisnp/research/regional/wks02/brockhtm

Buckley, Cynthia (1995) “The Myth of Managed Migration” Slavic Review, 54, 4 (1995), 896916.

Clayton, Elizabeth, and Thomas Richardson, (1989) "Soviet Control of City Size" Economic Development and Cultural Change, 38, 1 (1989), 155-65.

Gang, Ira N., and Robert C. Stuart (1999) "Mobility Where Mobility is Illegal: Internal Migration and City Growth in the Soviet Union" Journal of Population Economics, 12, 1 (1999), $117-34$.

Gang, Ira N., and Robert C. Stuart (2002) "The Political Economy of Russian City Growth," Economic Development and Cultural Change 50, 3 (April, 2002), 491-508.

Gerber, Theodore (2000) "Russia's Population Crisis: The Migration Dimension," Arizona State University, PONARS Policy Memo 118, May 2000.

Global Security (2004) "Secret Cities," http://globalsecurity.org/wmd/world/russia/secrfet-cities.htm

Goskomstat Rossii, Regiony Rossii (Regions of Russia) vols 1 and 2 (Moscow: Goskomstat, 2001).

Grandstaff, Peter J., (1980) Interregional Migration in The USSR: Economic Aspects (Durham, N.C.: Duke University Press, 1980).

Harris, Chauncey (1972) Cities of the Soviet Union (Chicago: Rand McNaly, 1972).

Heleniak, Timothy (2002) "Migration Dilemmas Haunt Post-Soviet Russia" (Washington, D.C.: Migration Policy Institute).

Kazuhiro, Kumo (2003) Migration and Regional Development in the Soviet Union and Russia: A Geographical Approach (Moscow: Beck Publishers, 2003). 
Kutepova, Nadezdha "Closed Cities as Evil of Russia"

http://www.edi.cdi.org/russia/johnson/7068-7.cfm (David Johnson, Editor).

Lewis, Robert A., and Robert H. Rowland (1979) Population Redistribution in the USSR: Its Impact on Society,1897-1977 (New York: Praeger, ).

Mitchnek, Beth A., (1990) Geographical and Economic Determinants of Interregional Migration in The USSR, 1967-1985, (New York: Columbia University, Phd dissertation, 1990).

Morton, Henry W., and Robert C. Stuart(1984) The Contemporary Soviet City (Armonk, N.Y.: M.E. Sharpe).

"Ob itogakh Vserossiiskoi perepisi naseleniia 2002 goda" (About the results of the All-Russian census of the population of 2002).

http://www.eastview.com/census_2002/report.pdf

Ofer, Gur (1977) "Economizing on Urbanization in Socialist Countries: Historical Necessity or Socialist Strategy?" in Alan A.Brown and Egon Neuberger (eds), Internal Migration: A Comparative Perspective (New York: Academic Press, 1977).

"Rossiiskii statisticheskii ezhegodnik" (Russian statistical yearbook).

Szabo G. (2001) "Russia's Closed Cities Are Open and Shut Case" http://www.therussiajournal.com/index.htm?obj=5246 


\section{APPENDIX A: Data Definitions and Sources}

Background - We assembled a database on 171 cities and the 78 oblasts in which they are located. These are all non-secret cities having a population of 50,000 or more as of 1959. The issue of defining regional units in Russia is one of long standing complexity and controversy. Moreover, important changes have occurred in the post-Soviet era. Our characterization is driven by the availability of data. Russia is divided into twelve large regions (Kaliningrad, North, North-west, Central, Volga-Viatka, Central Black Earth, Volga, North Caucasus, Urals, West Siberia, East Siberia, Far East). Within each of these large regions, the dominant subunit is the oblast. The large regions vary in size and there is also variation in the structure of oblasts. Moreover, some oblasts have been re-classified, for example, as republics. Although some units within our twelve regions are not oblasts (krai, republic, etc.), we use the term oblast to describe all such units.

Cities that were added to the previous Gang and Stuart (2002) dataset are Grozny, Korolev, Seversk, and Vorkuta. We also dropped Kaliningrad in Moskow oblast from the dataset. We don't have any data on Grozny for 1993-1995, 1997-2001 because of the Chechen war and for Kolpino for 1999-2002 because it became part of St.Petersburg.

Specific controls to limit the growth of some (though not all) Soviet cities were mostly put in place in 1956. Restrictions were either total (limitation on issuance of a propiska) or expansion (limitation on the development of industrial enterprises). For a discussion of these controls, see (Lewis and Rowland, Buckley, Gang and Stuart (1999). Of the 171 cities we include in this study, 30 were subject to a total restriction, while 16 were subject to an expansion restriction. Thus 46 of our 171 cities were administratively controlled in some fashion. Some cities were also administrative and may have been favored to receive scarce resources and administrative attention. Seventy of our 171 cities were capitals of the oblasts in which they were located. Controls in Russia during the command era were much more pervasive than those pertaining to city growth. For example, there was a system of required placement of university graduates, and a widely used system of organized recruitment for labor (orgnabor) redistributing labor from surplus to deficit regions. At the same time, there were market-type incentives, for example regional wage differentials, to which members of the population could and did respond.

For the cities in our sample, we compute the growth occurring in 1960, 1965, 1970, 1975 , 1980, 1985, 1990, 1995, 2000, and 2002 from net migration. We have actual data for the years 1959, 1970, 1975, 1979, 1985, 1989, 1991, 1995, 2000, and 2002 and interpolated data for 1960, 1965, 1980, 1990. Using available and interpolated population data, we are able to calculate annualized rates of population growth as well as the rate of natural increase (birth rate-death rate). To interpolate, we use the method cubic splines available in Stata7 (2000). The net migration rate for each city was computed by subtracting the rate of natural increase (birth rates and death rates by oblast) from the annualized growth rate of the population. While we have a sample of 171 cities whose net migration can be examined, we do not know whether the source of this migration is from a different city or from a rural area.

Net Migration Rate - This is the population growth rate minus the rate of natural increase. Here we calculate the rate per 100 (see the above description for its calculation). Source: see city population, below. 
Controls: Expansion and Total Restrictions - Specific controls to limit the growth of some (though not all) Soviet cities were mostly put in place in 1956. Information on controls from Cynthia Buckley, 1995, "The Myth of Managed Migration: Migration Control and Market in the Soviet Period," Slavic Review 54, 4 (Winter); R.A. Lewis and R.H. Rowland, 1979, Population Redistribution in the USSR: Its Impact on Society, 1987-1977 (New York: Praeger Publishers); Ira N. Gang and Robert C. Stuart, 1999, "Mobility Where Mobility is Illegal: Internal Migration and City Growth in the Soviet Union," Journal of Population Economics 12, $1,117-34$.

City Population, Oblast Capital, Oblast, Regions - Cities are all known cities with a population over 50,000 in 1959. We use census year data and interpolate using a cublic spline interpolation. Sources: From Soviet handbooks on population (Naselenie SSSR), the annual statistical handbooks (Narodnoe khoziaistvo SSSR and Rossiiskii statisticheskii ezhegodnik), the census volumes (Itogi vsesoiuznoi perepisi naseleniia) and the Soviet statistical journal (Vestnik statistiki).

Urban share - City population/urban population of region.

Capital dummy - equals 1 if the city is an oblast capital and equals 0 otherwise. 
Table 1: Aggregate Statistics

\begin{tabular}{|c|c|c|c|c|c|c|c|c|c|c|c|c|c|c|c|c|c|c|c|}
\hline & 1960 & 1965 & \begin{tabular}{|l|l}
1970 \\
\end{tabular} & 1975 & 1980 & 1985 & 1990 & 1991 & 1992 & 1993 & 1994 & 1995 & 1996 & 1997 & 1998 & \begin{tabular}{|l|}
1999 \\
\end{tabular} & 2000 & 2001 & 2002 \\
\hline $\begin{array}{l}\text { Population } \\
\text { (in mil) }\end{array}$ & 117.5 & 127.9 & 130.1 & 134.7 & 137.6 & 143.8 & 148.0 & 148.5 & 148.7 & 148.7 & 148.4 & 148.3 & 148.0 & 147.5 & 147.1 & 146.7 & 145.9 & 145.5 & 145.2 \\
\hline Urban & 61.6 & 74.7 & 81.0 & 91.1 & 95.4 & 104.2 & 109.2 & 109.8 & 109.7 & 108.9 & 108.5 & 108.4 & 108.1 & 107.8 & 107.5 & \begin{tabular}{|l|}
107.3 \\
\end{tabular} & 106.5 & 106.1 & 106.5 \\
\hline Rural & 55.9 & 53.0 & 49.1 & 43.6 & 42.2 & 39.7 & 38.8 & 38.7 & 39.0 & 39.8 & 39.9 & 40.0 & 39.9 & 39.7 & 39.6 & 39.4 & 39.4 & 39.4 & 38.7 \\
\hline \multicolumn{20}{|c|}{ Proportion of population living in restricted cities } \\
\hline$\%$ of urban & 42.8 & 41.6 & 43.9 & 42.0 & 43.8 & 41.2 & 42.8 & 40.2 & 40.2 & 39.9 & 39.8 & 39.7 & 39.8 & 39.7 & 39.7 & 39.7 & 39.8 & 39.6 & 41.0 \\
\hline$\%$ of total & 22.5 & 24.3 & 27.3 & 28.4 & 30.4 & 29.9 & 31.8 & 29.7 & 29.6 & 29.2 & 29.1 & 29.0 & 29.1 & 29.0 & 29.0 & 29.0 & 29.0 & 28.9 & 30.1 \\
\hline \multicolumn{20}{|c|}{ Sample of 171 cities } \\
\hline Population & 38.7 & 44.2 & 50.6 & 57.8 & 61.8 & 66.4 & 69.0 & 69.0 & 69.1 & 68.4 & 68.1 & 68.0 & 68.1 & 67.8 & 67.7 & 67.5 & 67.2 & 66.7 & 68.4 \\
\hline $\begin{array}{l}\text { \% of } \\
\text { population } \\
\text { living in } \\
\text { restricted } \\
\text { cities }\end{array}$ & 69.8 & 68.6 & 67.4 & 66.2 & 65.4 & 64.7 & 64.1 & 64.0 & 63.8 & 63.5 & 63.3 & 63.2 & 63.2 & 63.1 & 62.1 & 63.1 & 63.1 & 62.9 & 63.9 \\
\hline
\end{tabular}

Source: computed by the authors (see Appendix A). ${ }^{6}$

\footnotetext{
${ }^{6}$ Years 1960, 1980 are 1959, 1979 census. Years 1965 and 1990 are interpolated.
} 
Table 2: Direct Administrative Controls

\begin{tabular}{|c|c|c|c|c|}
\hline & $\begin{array}{c}\text { Number of } \\
\text { Cities in } \\
\text { Sample } \\
\end{array}$ & $\begin{array}{c}\text { Number } \\
\text { Totally } \\
\text { Restricted }\end{array}$ & $\begin{array}{c}\text { Number } \\
\text { Expansion } \\
\text { Restricted } \\
\end{array}$ & $\begin{array}{c}\text { Number } \\
\text { Unrestricted }\end{array}$ \\
\hline \multicolumn{5}{|l|}{ Overall Measure } \\
\hline Russia & 171 & 30 & 16 & 125 \\
\hline \multicolumn{5}{|c|}{ Administrative Function of City } \\
\hline Oblast Capital & 70 & 25 & 12 & 33 \\
\hline Others & 101 & 5 & 4 & 92 \\
\hline \multicolumn{5}{|l|}{ Geographic regions } \\
\hline $\begin{array}{l}\text { Vostochno- } \\
\text { Sibirskiy }\end{array}$ & 12 & 0 & 2 & 2 \\
\hline Povolzhskiy & 18 & 4 & 2 & 12 \\
\hline Zapadno-Sibirskiy & 17 & 2 & 5 & 10 \\
\hline $\begin{array}{l}\text { Kaliningradskaya } \\
\text { oblast' }\end{array}$ & 1 & 0 & 0 & 1 \\
\hline Severnyi & 8 & 2 & 0 & 6 \\
\hline Severo-Zapadnyi & 6 & 1 & 0 & 5 \\
\hline Severo-Kavkazskiy & 18 & 3 & 0 & 15 \\
\hline Volgo-Vyatskiy & 8 & 1 & 2 & 5 \\
\hline Central'nyi & 33 & 6 & 1 & 26 \\
\hline $\begin{array}{l}\text { Central'no- } \\
\text { Chernozemnyi }\end{array}$ & 8 & 1 & 1 & 6 \\
\hline Ural'skiy & 23 & 5 & 2 & 16 \\
\hline Dal'nevostochnyi & 11 & 3 & 0 & 8 \\
\hline
\end{tabular}

Source: Appendix A. 
Table 3: Incidence of Restrictions by City Size

\begin{tabular}{|c|c|c|c|c|c|c|c|c|c|c|c|c|c|}
\hline \multirow{2}{*}{\begin{tabular}{|l|} 
Type of \\
Restriction \\
\end{tabular}} & \multirow{2}{*}{$\begin{array}{c}\text { City Size } \\
(000)\end{array}$} & \multicolumn{12}{|c|}{ Number of Cities } \\
\hline & & 1960 & 1965 & 1970 & 1975 & 1980 & 1985 & 1988 & 1989 & 1990 & 1995 & 2000 & 2002 \\
\hline \multirow{4}{*}{$\begin{array}{l}\text { Total } \\
\text { Restriction }\end{array}$} & $<250$ & 4 & 2 & 1 & 1 & 0 & 0 & 0 & 0 & 0 & 0 & 1 & 2 \\
\hline & $250-500$ & 13 & 14 & 14 & 10 & 11 & 10 & 9 & 9 & 9 & 8 & 7 & 8 \\
\hline & $500-1000$ & 11 & 10 & 9 & 13 & 10 & 10 & 10 & 10 & 9 & 9 & 10 & 8 \\
\hline & $>1000$ & 2 & 4 & 6 & 6 & 9 & 10 & 11 & 11 & 12 & 13 & 12 & 12 \\
\hline \multirow{4}{*}{$\begin{array}{l}\text { Expansion } \\
\text { Restriction }\end{array}$} & $<250$ & 7 & 4 & 2 & 2 & 1 & 0 & 0 & 0 & 0 & 1 & 1 & 1 \\
\hline & $250-500$ & 8 & 10 & 12 & 10 & 10 & 8 & 7 & 6 & 8 & 8 & 9 & 7 \\
\hline & $500-1000$ & 1 & 2 & 2 & 4 & 4 & 7 & 8 & 9 & 7 & 7 & 6 & 7 \\
\hline & $>1000$ & 0 & 0 & 0 & 0 & 1 & 1 & 1 & 1 & 1 & 0 & 0 & 1 \\
\hline \multirow[t]{4}{*}{$\begin{array}{l}\text { Never } \\
\text { Restricted }\end{array}$} & $<250$ & 123 & 122 & 119 & 109 & 102 & 99 & 95 & 95 & 93 & 94 & 95 & 101 \\
\hline & $250-500$ & 2 & 3 & 6 & 14 & 21 & 24 & 28 & 27 & 29 & 28 & 25 & 27 \\
\hline & $500-1000$ & 0 & 0 & 0 & 2 & 2 & 2 & 2 & 3 & 3 & 3 & 5 & 5 \\
\hline & $>1000$ & 0 & 0 & 0 & 0 & 0 & 0 & 0 & 0 & 0 & 0 & 0 & 0 \\
\hline
\end{tabular}

Sources: See Appendix A .

\footnotetext{
${ }^{7}$ See table 1.
} 
Table 4: Net Migration Rate (in \%, weighted by population)

\begin{tabular}{|c|c|c|c|c|c|c|c|c|c|c|c|}
\hline & 1960 & 1965 & 1970 & 1975 & 1980 & 1985 & 1990 & 1995 & 1999 & 2000 & 2002 \\
\hline \multicolumn{12}{|c|}{ Overall Measure } \\
\hline Sample & $\begin{array}{c}1.28 \\
(0.01)\end{array}$ & $\begin{array}{c}2.21 \\
(0.02)\end{array}$ & $\begin{array}{c}2.26 \\
(0.02)\end{array}$ & $\begin{array}{c}1.69 \\
(0.01)\end{array}$ & $\begin{array}{c}1.08 \\
(0.01)\end{array}$ & $\begin{array}{c}0.85 \\
(0.01)\end{array}$ & $\begin{array}{c}0.03 \\
(0.01)\end{array}$ & $\begin{array}{c}0.51 \\
(0.01)\end{array}$ & $\begin{array}{c}0.57 \\
(0.01)\end{array}$ & $\begin{array}{c}0.30 \\
(0.01)\end{array}$ & $\begin{array}{c}0.69 \\
(0.00)\end{array}$ \\
\hline \multicolumn{12}{|c|}{ Restrictions } \\
\hline Total & $\begin{array}{c}0.96 \\
(0.02)\end{array}$ & $\begin{array}{c}1.61 \\
(0.05)\end{array}$ & $\begin{array}{c}1.64 \\
(0.07)\end{array}$ & $\begin{array}{c}1.23 \\
(0.03)\end{array}$ & $\begin{array}{c}0.77 \\
(0.05)\end{array}$ & $\begin{array}{c}0.64 \\
(0.04)\end{array}$ & $\begin{array}{l}-0.04 \\
(0.04)\end{array}$ & $\begin{array}{c}0.24 \\
(0.02)\end{array}$ & $\begin{array}{c}0.56 \\
(0.04)\end{array}$ & $\begin{array}{c}0.32 \\
(0.03)\end{array}$ & $\begin{array}{c}0.8 \\
(0.02)\end{array}$ \\
\hline Expansion & $\begin{array}{c}1.47 \\
(0.06)\end{array}$ & $\begin{array}{c}2.52 \\
(0.07)\end{array}$ & $\begin{array}{c}2.91 \\
(0.08)\end{array}$ & $\begin{array}{c}2.04 \\
(0.07)\end{array}$ & $\begin{array}{c}1.26 \\
(0.04)\end{array}$ & $\begin{array}{c}1.02 \\
(0.03)\end{array}$ & $\begin{array}{l}-0.24 \\
(0.09)\end{array}$ & $\begin{array}{c}0.86 \\
(0.03)\end{array}$ & $\begin{array}{c}0.47 \\
(0.03)\end{array}$ & $\begin{array}{c}0.21 \\
(0.03)\end{array}$ & $\begin{array}{c}0.64 \\
(0.01)\end{array}$ \\
\hline None & $\begin{array}{c}1.83 \\
(0.02)\end{array}$ & $\begin{array}{c}3.19 \\
(0.03)\end{array}$ & $\begin{array}{c}3.07 \\
(0.03)\end{array}$ & $\begin{array}{c}2.28 \\
(0.01)\end{array}$ & $\begin{array}{c}1.49 \\
(0.02)\end{array}$ & $\begin{array}{c}1.10 \\
(0.01)\end{array}$ & $\begin{array}{c}0.24 \\
(0.02)\end{array}$ & $\begin{array}{c}0.75 \\
(0.01)\end{array}$ & $\begin{array}{c}0.62 \\
(0.02)\end{array}$ & $\begin{array}{c}0.29 \\
(0.01)\end{array}$ & $\begin{array}{c}0.59 \\
(0.00)\end{array}$ \\
\hline \multicolumn{12}{|c|}{ City Size (000) } \\
\hline$<250$ & $\begin{array}{c}1.39 \\
(0.02)\end{array}$ & $\begin{array}{c}2.64 \\
(0.03)\end{array}$ & $\begin{array}{c}2.41 \\
(0.02)\end{array}$ & $\begin{array}{c}1.91 \\
(0.02)\end{array}$ & $\begin{array}{c}1.24 \\
(0.02)\end{array}$ & $\begin{array}{c}0.94 \\
(0.01)\end{array}$ & $\begin{array}{c}0.17 \\
(0.03)\end{array}$ & $\begin{array}{c}0.47 \\
(0.02)\end{array}$ & $\begin{array}{c}0.36 \\
(0.01)\end{array}$ & $\begin{array}{c}0.14 \\
(0.01)\end{array}$ & $\begin{array}{c}0.64 \\
(0.00)\end{array}$ \\
\hline $250-500$ & $\begin{array}{c}1.79 \\
(0.03)\end{array}$ & $\begin{array}{c}2.83 \\
(0.05)\end{array}$ & $\begin{array}{c}2.63 \\
(0.03)\end{array}$ & $\begin{array}{c}1.85 \\
(0.02)\end{array}$ & $\begin{array}{c}1.34 \\
(0.03)\end{array}$ & $\begin{array}{c}1.01 \\
(0.02)\end{array}$ & $\begin{array}{l}-0.04 \\
(0.04)\end{array}$ & $\begin{array}{c}0.91 \\
(0.02)\end{array}$ & $\begin{array}{c}0.46 \\
(0.02)\end{array}$ & $\begin{array}{c}0.39 \\
(0.04)\end{array}$ & $\begin{array}{c}0.65 \\
(0.01)\end{array}$ \\
\hline $500-1000$ & $\begin{array}{c}1.86 \\
(0.05)\end{array}$ & $\begin{array}{c}2.97 \\
(0.07)\end{array}$ & $\begin{array}{c}3.25 \\
(0.10)\end{array}$ & $\begin{array}{c}2.26 \\
(0.05)\end{array}$ & $\begin{array}{c}1.28 \\
(0.04)\end{array}$ & $\begin{array}{c}1.06 \\
(0.03)\end{array}$ & $\begin{array}{c}0.19 \\
(0.06)\end{array}$ & $\begin{array}{c}0.92 \\
(0.04)\end{array}$ & $\begin{array}{c}0.81 \\
(0.08)\end{array}$ & $\begin{array}{c}0.21 \\
(0.03)\end{array}$ & $\begin{array}{c}0.91 \\
(0.02)\end{array}$ \\
\hline$>1000$ & $\begin{array}{c}0.79 \\
(0.04)\end{array}$ & $\begin{array}{c}1.38 \\
(0.09)\end{array}$ & $\begin{array}{c}1.58 \\
(0.13)\end{array}$ & $\begin{array}{c}1.23 \\
(0.08)\end{array}$ & $\begin{array}{c}0.79 \\
(0.10)\end{array}$ & $\begin{array}{c}0.63 \\
(0.09)\end{array}$ & $\begin{array}{l}-0.08 \\
(0.08)\end{array}$ & $\begin{array}{c}0.07 \\
(0.03)\end{array}$ & $\begin{array}{c}0.63 \\
(0.07)\end{array}$ & $\begin{array}{c}0.37 \\
(0.07)\end{array}$ & $\begin{array}{c}0.77 \\
(0.44)\end{array}$ \\
\hline \multicolumn{12}{|c|}{ Administrative Function of City } \\
\hline $\begin{array}{l}\text { Oblast } \\
\text { Capital }\end{array}$ & $\begin{array}{c}1.22 \\
(0.01)\end{array}$ & $\begin{array}{c}1.96 \\
(0.03)\end{array}$ & $\begin{array}{c}2.10 \\
(0.04)\end{array}$ & $\begin{array}{c}1.56 \\
(0.01)\end{array}$ & $\begin{array}{c}0.98 \\
(0.02)\end{array}$ & $\begin{array}{c}0.80 \\
(0.02)\end{array}$ & $\begin{array}{l}-0.03 \\
(0.02)\end{array}$ & $\begin{array}{c}0.45 \\
(0.01)\end{array}$ & $\begin{array}{c}0.63 \\
(0.02)\end{array}$ & $\begin{array}{c}0.27 \\
(0.02)\end{array}$ & $\begin{array}{c}0.72 \\
(0.01)\end{array}$ \\
\hline Others & $\begin{array}{c}1.47 \\
(0.02)\end{array}$ & $\begin{array}{c}2.98 \\
(0.04)\end{array}$ & $\begin{array}{c}2.74 \\
(0.05)\end{array}$ & $\begin{array}{c}2.04 \\
(0.02)\end{array}$ & $\begin{array}{c}1.38 \\
(0.03)\end{array}$ & $\begin{array}{c}1.01 \\
(0.02)\end{array}$ & $\begin{array}{c}0.19 \\
(0.02)\end{array}$ & $\begin{array}{c}0.68 \\
(0.02)\end{array}$ & $\begin{array}{c}0.40 \\
(0.01)\end{array}$ & $\begin{array}{c}0.35 \\
(0.02)\end{array}$ & $\begin{array}{c}0.63 \\
(0.00)\end{array}$ \\
\hline
\end{tabular}


Table 5: Net Migration Rate (in \%, weighted by population)

\begin{tabular}{|c|c|c|c|c|c|c|c|c|c|c|c|}
\hline $\begin{array}{l}\text { Geographic } \\
\text { regions }\end{array}$ & 1960 & 1965 & 1970 & 1975 & 1980 & 1985 & 1990 & 1995 & 1999 & 2000 & 2002 \\
\hline $\begin{array}{l}\text { Vostochno- } \\
\text { Sibirskiy }\end{array}$ & $\begin{array}{c}1.93 \\
(0.21)\end{array}$ & $\begin{array}{c}3.42 \\
(0.39)\end{array}$ & $\begin{array}{c}2.81 \\
(0.21)\end{array}$ & $\begin{array}{c}1.86 \\
(0.09)\end{array}$ & $\begin{array}{c}0.98 \\
(0.11)\end{array}$ & $\begin{array}{c}0.67 \\
(0.09)\end{array}$ & $\begin{array}{l}-1.46 \\
(0.23)\end{array}$ & $\begin{array}{c}0.27 \\
(0.08)\end{array}$ & $\begin{array}{c}0.31 \\
(0.09)\end{array}$ & $\begin{array}{c}0.73 \\
(0.26)\end{array}$ & $\begin{array}{c}0.35 \\
(0.03) \\
\end{array}$ \\
\hline Povolzhskiy & $\begin{array}{c}1.86 \\
(0.07)\end{array}$ & $\begin{array}{c}3.25 \\
(0.14)\end{array}$ & $\begin{array}{c}3.62 \\
(0.26)\end{array}$ & $\begin{array}{c}2.55 \\
(0.13)\end{array}$ & $\begin{array}{c}1.28 \\
(0.10)\end{array}$ & $\begin{array}{c}0.91 \\
(0.07)\end{array}$ & $\begin{array}{c}0.00 \\
(0.10)\end{array}$ & $\begin{array}{c}0.81 \\
(0.06)\end{array}$ & $\begin{array}{c}0.72 \\
(0.06)\end{array}$ & $\begin{array}{c}0.30 \\
(0.04)\end{array}$ & $\begin{array}{c}0.60 \\
(0.03)\end{array}$ \\
\hline $\begin{array}{l}\text { Zapadno- } \\
\text { Sibirskiy }\end{array}$ & $\begin{array}{c}0.82 \\
(0.08)\end{array}$ & $\begin{array}{c}2.04 \\
(0.14)\end{array}$ & $\begin{array}{c}1.83 \\
(0.14)\end{array}$ & $\begin{array}{c}1.23 \\
(0.09)\end{array}$ & $\begin{array}{c}1.14 \\
(0.10)\end{array}$ & $\begin{array}{c}0.83 \\
(0.05)\end{array}$ & $\begin{array}{l}-0.60 \\
(0.09)\end{array}$ & $\begin{array}{c}0.40 \\
(0.03)\end{array}$ & $\begin{array}{c}0.38 \\
(0.05)\end{array}$ & $\begin{array}{l}-0.05 \\
(0.03)\end{array}$ & $\begin{array}{c}0.42 \\
(0.03)\end{array}$ \\
\hline $\begin{array}{l}\text { Kaliningrad } \\
\text { skaya } \\
\text { oblast' }\end{array}$ & $\begin{array}{c}1.35 \\
(0.00)\end{array}$ & $\begin{array}{c}2.75 \\
(0.00)\end{array}$ & $\begin{array}{c}2.20 \\
(0.00)\end{array}$ & $\begin{array}{c}1.19 \\
(0.00)\end{array}$ & $\begin{array}{c}0.77 \\
(0.00)\end{array}$ & $\begin{array}{c}0.67 \\
(0.00)\end{array}$ & $\begin{array}{c}0.54 \\
(0.00)\end{array}$ & $\begin{array}{l}1.46 \\
(0.00)\end{array}$ & $\begin{array}{c}0.96 \\
(0.00)\end{array}$ & $\begin{array}{l}-0.01 \\
(0.00)\end{array}$ & $\begin{array}{c}0.87 \\
(0.00)\end{array}$ \\
\hline Severnyi & $\begin{array}{c}1.93 \\
(0.17)\end{array}$ & $\begin{array}{c}2.97 \\
(0.25)\end{array}$ & $\begin{array}{c}2.81 \\
(0.13)\end{array}$ & $\begin{array}{c}1.95 \\
(0.09)\end{array}$ & $\begin{array}{c}1.39 \\
(0.12)\end{array}$ & $\begin{array}{c}1.04 \\
(0.07)\end{array}$ & $\begin{array}{l}-0.83 \\
(0.29)\end{array}$ & $\begin{array}{c}0.23 \\
(0.17)\end{array}$ & $\begin{array}{c}0.24 \\
(0.13)\end{array}$ & $\begin{array}{l}-0.23 \\
(0.11)\end{array}$ & $\begin{array}{c}0.59 \\
(0.04)\end{array}$ \\
\hline $\begin{array}{l}\text { Severo- } \\
\text { Zapadnyi }\end{array}$ & $\begin{array}{c}0.92 \\
(0.19)\end{array}$ & $\begin{array}{c}1.30 \\
(0.26)\end{array}$ & $\begin{array}{c}1.84 \\
(0.39)\end{array}$ & $\begin{array}{c}1.49 \\
(0.31)\end{array}$ & $\begin{array}{c}1.03 \\
(0.22)\end{array}$ & $\begin{array}{c}0.88 \\
(0.19)\end{array}$ & $\begin{array}{c}0.53 \\
(0.11)\end{array}$ & $\begin{array}{c}0.13 \\
(0.02)\end{array}$ & $\begin{array}{c}0.53 \\
(0.13)\end{array}$ & $\begin{array}{c}0.28 \\
(0.06)\end{array}$ & $\begin{array}{c}0.91 \\
(0.23)\end{array}$ \\
\hline $\begin{array}{l}\text { Severo- } \\
\text { Kavkazskiy }\end{array}$ & $\begin{array}{c}1.33 \\
(0.07) \\
\end{array}$ & $\begin{array}{c}2.10 \\
(0.09) \\
\end{array}$ & $\begin{array}{c}2.14 \\
(0.09) \\
\end{array}$ & $\begin{array}{c}1.67 \\
(0.07) \\
\end{array}$ & $\begin{array}{c}1.09 \\
(0.07) \\
\end{array}$ & $\begin{array}{c}0.77 \\
(0.04) \\
\end{array}$ & $\begin{array}{c}0.50 \\
(0.03) \\
\end{array}$ & $\begin{array}{c}1.32 \\
(0.06) \\
\end{array}$ & $\begin{array}{c}0.15 \\
(0.02) \\
\end{array}$ & $\begin{array}{l}-0.11 \\
(0.02)\end{array}$ & $\begin{array}{c}0.50 \\
(0.02) \\
\end{array}$ \\
\hline $\begin{array}{l}\text { Volgo- } \\
\text { Vyatskiy }\end{array}$ & $\begin{array}{c}1.65 \\
(0.14)\end{array}$ & $\begin{array}{c}2.74 \\
(0.22)\end{array}$ & $\begin{array}{c}2.95 \\
(0.17)\end{array}$ & $\begin{array}{c}2.06 \\
(0.12)\end{array}$ & $\begin{array}{c}1.35 \\
(0.10)\end{array}$ & $\begin{array}{c}1.16 \\
(0.08)\end{array}$ & $\begin{array}{c}0.48 \\
(0.11)\end{array}$ & $\begin{array}{c}0.02 \\
(0.14)\end{array}$ & $\begin{array}{c}0.65 \\
(0.07)\end{array}$ & $\begin{array}{c}0.49 \\
(0.05)\end{array}$ & $\begin{array}{c}0.90 \\
(0.09)\end{array}$ \\
\hline Central'nyi & $\begin{array}{c}1.09 \\
(0.03)\end{array}$ & $\begin{array}{c}1.72 \\
(0.04)\end{array}$ & $\begin{array}{c}1.96 \\
(0.05)\end{array}$ & $\begin{array}{c}1.60 \\
(0.05)\end{array}$ & $\begin{array}{c}1.02 \\
(0.03)\end{array}$ & $\begin{array}{c}0.92 \\
(0.03)\end{array}$ & $\begin{array}{c}0.60 \\
(0.02)\end{array}$ & $\begin{array}{c}0.53 \\
(0.02)\end{array}$ & $\begin{array}{c}0.69 \\
(0.02)\end{array}$ & $\begin{array}{c}0.60 \\
(0.02)\end{array}$ & $\begin{array}{c}0.96 \\
(0.03)\end{array}$ \\
\hline $\begin{array}{l}\text { Central'no- } \\
\text { Chernozem } \\
\text { nyi }\end{array}$ & $\begin{array}{c}2.22 \\
(0.27)\end{array}$ & $\begin{array}{c}3.16 \\
(0.33)\end{array}$ & $\begin{array}{c}3.54 \\
(0.26)\end{array}$ & $\begin{array}{c}2.81 \\
(0.18)\end{array}$ & $\begin{array}{c}1.97 \\
(0.11)\end{array}$ & $\begin{array}{c}1.49 \\
(0.08)\end{array}$ & $\begin{array}{c}1.53 \\
(0.07)\end{array}$ & $\begin{array}{c}1.54 \\
(0.08)\end{array}$ & $\begin{array}{c}2.62 \\
(0.35)\end{array}$ & $\begin{array}{c}0.88 \\
(0.07)\end{array}$ & $\begin{array}{c}0.93 \\
(0.06)\end{array}$ \\
\hline Ural'skiy & $\begin{array}{c}1.03 \\
(0.05)\end{array}$ & $\begin{array}{c}1.89 \\
(0.07)\end{array}$ & $\begin{array}{c}1.67 \\
(0.07)\end{array}$ & $\begin{array}{c}1.23 \\
(0.06)\end{array}$ & $\begin{array}{c}0.80 \\
(0.03)\end{array}$ & $\begin{array}{c}0.49 \\
(0.02)\end{array}$ & $\begin{array}{l}-1.09 \\
(0.06)\end{array}$ & $\begin{array}{c}0.48 \\
(0.02)\end{array}$ & $\begin{array}{c}0.44 \\
(0.02)\end{array}$ & $\begin{array}{c}0.23 \\
(0.01)\end{array}$ & $\begin{array}{c}0.55 \\
(0.02)\end{array}$ \\
\hline $\begin{array}{l}\text { Dal'nevosto } \\
\text { chnyi }\end{array}$ & $\begin{array}{c}1.06 \\
(0.11)\end{array}$ & $\begin{array}{c}1.77 \\
(0.13)\end{array}$ & $\begin{array}{c}2.32 \\
(0.12)\end{array}$ & $\begin{array}{c}1.71 \\
(0.08)\end{array}$ & $\begin{array}{c}0.92 \\
(0.04)\end{array}$ & $\begin{array}{c}0.85 \\
(0.04)\end{array}$ & $\begin{array}{c}0.08 \\
(0.15)\end{array}$ & $\begin{array}{l}-0.73 \\
(0.07)\end{array}$ & $\begin{array}{l}-0.07 \\
(0.04)\end{array}$ & $\begin{array}{l}-0.40 \\
(0.04)\end{array}$ & $\begin{array}{c}0.37 \\
(0.03)\end{array}$ \\
\hline
\end{tabular}

Source: see Appendix A. 
Table 6: Effect of Restrictions on Net Migration (OLS, White Standard Errors)

(dependent variable $=$ net migration rate, $\mathrm{n}=171$ )

\begin{tabular}{|c|c|c|c|c|c|c|c|c|c|c|}
\hline Year & 1960 & 1965 & 1970 & 1975 & 1980 & 1985 & 1990 & 1995 & 2000 & 2002 \\
\hline Expansion Restriction & $\begin{array}{c}0.00 \\
(0.00)\end{array}$ & $\begin{array}{l}-0.21 \\
(0.81)\end{array}$ & $\begin{array}{l}-0.47 \\
(1.19)\end{array}$ & $\begin{array}{l}-0.39 \\
(0.53)\end{array}$ & $\begin{array}{l}-0.31 \\
(0.32)\end{array}$ & $\begin{array}{c}0.00 \\
(0.21)\end{array}$ & $\begin{array}{l}-0.54 \\
(0.40)\end{array}$ & $\begin{array}{c}0.26 \\
(0.19)\end{array}$ & $\begin{array}{l}-0.10 \\
(0.17)\end{array}$ & $\begin{array}{c}0.00 \\
(0.00)\end{array}$ \\
\hline Total Restriction & $\begin{array}{c}0.00 \\
(0.00) \\
\end{array}$ & $\begin{array}{c}-1.72 \\
(1.20) \\
\end{array}$ & $\begin{array}{c}0.50 \\
(1.13) \\
\end{array}$ & $\begin{array}{c}-0.83^{*} \\
(0.42) \\
\end{array}$ & $\begin{array}{l}-0.66^{*} \\
(0.24) \\
\end{array}$ & $\begin{array}{l}-0.59^{*} \\
(0.18) \\
\end{array}$ & $\begin{array}{l}-0.51 \\
(0.41) \\
\end{array}$ & $\begin{array}{c}-0.40 \\
(0.25) \\
\end{array}$ & $\begin{array}{c}-0.31 \\
(0.22) \\
\end{array}$ & $\begin{array}{c}0.00^{* * *} \\
(0.00) \\
\end{array}$ \\
\hline Population/1000 & $\begin{array}{c}0.02 * \\
(0.01)\end{array}$ & $\begin{array}{c}3.54 \\
(6.00) \\
\end{array}$ & $\begin{array}{l}-9.57 * \\
(4.57) \\
\end{array}$ & $\begin{array}{c}-1.86 \\
(1.16) \\
\end{array}$ & $\begin{array}{l}-0.75 \\
(0.65) \\
\end{array}$ & $\begin{array}{c}0.00 \\
(0.25) \\
\end{array}$ & $\begin{array}{l}-0.41 \\
(0.64) \\
\end{array}$ & $\begin{array}{c}0.91 * * \\
(0.49)\end{array}$ & $\begin{array}{c}0.65 \\
(0.43) \\
\end{array}$ & $\begin{array}{l}0.01^{*} \\
(0.00)\end{array}$ \\
\hline Population Square $/ 1000^{2}$ & $\begin{array}{c}0.00 \\
(0.00) \\
\end{array}$ & $\begin{array}{c}-0.54 \\
(0.86) \\
\end{array}$ & $\begin{array}{l}1.25^{*} \\
(0.60)\end{array}$ & $\begin{array}{c}0.22^{* *} \\
(0.14)\end{array}$ & $\begin{array}{c}0.09 \\
(0.07) \\
\end{array}$ & $\begin{array}{c}0.01 \\
(0.03) \\
\end{array}$ & $\begin{array}{c}0.06 \\
(0.07) \\
\end{array}$ & $\begin{array}{c}-0.10 * * \\
(0.05)\end{array}$ & $\begin{array}{l}-0.06 \\
(0.05) \\
\end{array}$ & $\begin{array}{l}0.00^{*} \\
(0.00)\end{array}$ \\
\hline Region Capital & $\begin{array}{l}0.00^{*} \\
(0.00)\end{array}$ & $\begin{array}{c}0.92 \\
(0.95) \\
\end{array}$ & $\begin{array}{l}-0.37 \\
(0.94) \\
\end{array}$ & $\begin{array}{c}0.27 \\
(0.37) \\
\end{array}$ & $\begin{array}{c}0.03 \\
(0.27) \\
\end{array}$ & $\begin{array}{c}0.07 \\
(0.16) \\
\end{array}$ & $\begin{array}{c}0.09 \\
(0.42) \\
\end{array}$ & $\begin{array}{c}-0.08 \\
(0.30)\end{array}$ & $\begin{array}{c}-0.18 \\
(0.21) \\
\end{array}$ & $\begin{array}{c}0.00 \\
(0.00)\end{array}$ \\
\hline Urban & $\begin{array}{c}0.00 \\
(0.00)\end{array}$ & $\begin{array}{l}-0.11 \\
(0.15)\end{array}$ & $\begin{array}{c}0.33 \\
(0.21)\end{array}$ & $\begin{array}{c}0.10 \\
(0.08)\end{array}$ & $\begin{array}{c}0.06 \\
(0.07)\end{array}$ & $\begin{array}{l}0.59^{*} \\
(0.20)\end{array}$ & $\begin{array}{c}0.01 \\
(0.03)\end{array}$ & $\begin{array}{c}-0.10 * \\
(0.02)\end{array}$ & $\begin{array}{l}-0.03 \\
(0.03)\end{array}$ & $\begin{array}{l}0.00^{*} \\
(0.00)\end{array}$ \\
\hline Constant & $\begin{array}{c}0.00^{*} \\
(0.00) \\
\end{array}$ & $\begin{array}{c}1.45 \\
(2.24) \\
\end{array}$ & $\begin{array}{l}6.26^{*} \\
(1.91) \\
\end{array}$ & $\begin{array}{l}2.75^{*} \\
(0.44) \\
\end{array}$ & $\begin{array}{l}1.70^{*} \\
(0.31) \\
\end{array}$ & $\begin{array}{l}0.85^{*} \\
(0.12) \\
\end{array}$ & $\begin{array}{c}0.37 \\
(0.25) \\
\end{array}$ & $\begin{array}{l}0.47^{*} \\
(0.19)\end{array}$ & $\begin{array}{c}0.17 \\
(0.12) \\
\end{array}$ & $\begin{array}{c}0.00 \\
(0.00) \\
\end{array}$ \\
\hline R-bar squared & 0.67 & 0.00 & 0.03 & 0.04 & 0.03 & 0.11 & 0.02 & 0.03 & 0.01 & 0.97 \\
\hline R-bar squared adjusted & 0.66 & -0.03 & -0.01 & 0.00 & -0.01 & 0.08 & -0.02 & -0.01 & -0.02 & 0.97 \\
\hline p-value joint restrictions test & 0.39 & 0.21 & 0.83 & 0.15 & 0.03 & 0.00 & 0.26 & 0.05 & 0.38 & 0.19 \\
\hline $\begin{array}{l}\mathrm{p} \text {-value test of whether } \\
\text { coefficients on total and } \\
\text { expansion restrictions are the } \\
\text { same }\end{array}$ & 0.64 & 0.38 & 0.54 & 0.43 & 0.31 & 0.02 & 0.95 & 0.02 & 0.32 & 0.07 \\
\hline
\end{tabular}

Source: Authors' calculations using Eviews 3. ${ }^{8}$.

Notes: *significant at .05 level. **significant at .10 level.

\footnotetext{
${ }^{8}$ Calculations for $1960,1965,1980,1990$ were made using interpolated data.
} 
Figure1: Net Migration Rate (NMR) by Type of Restriction (1960-2002)

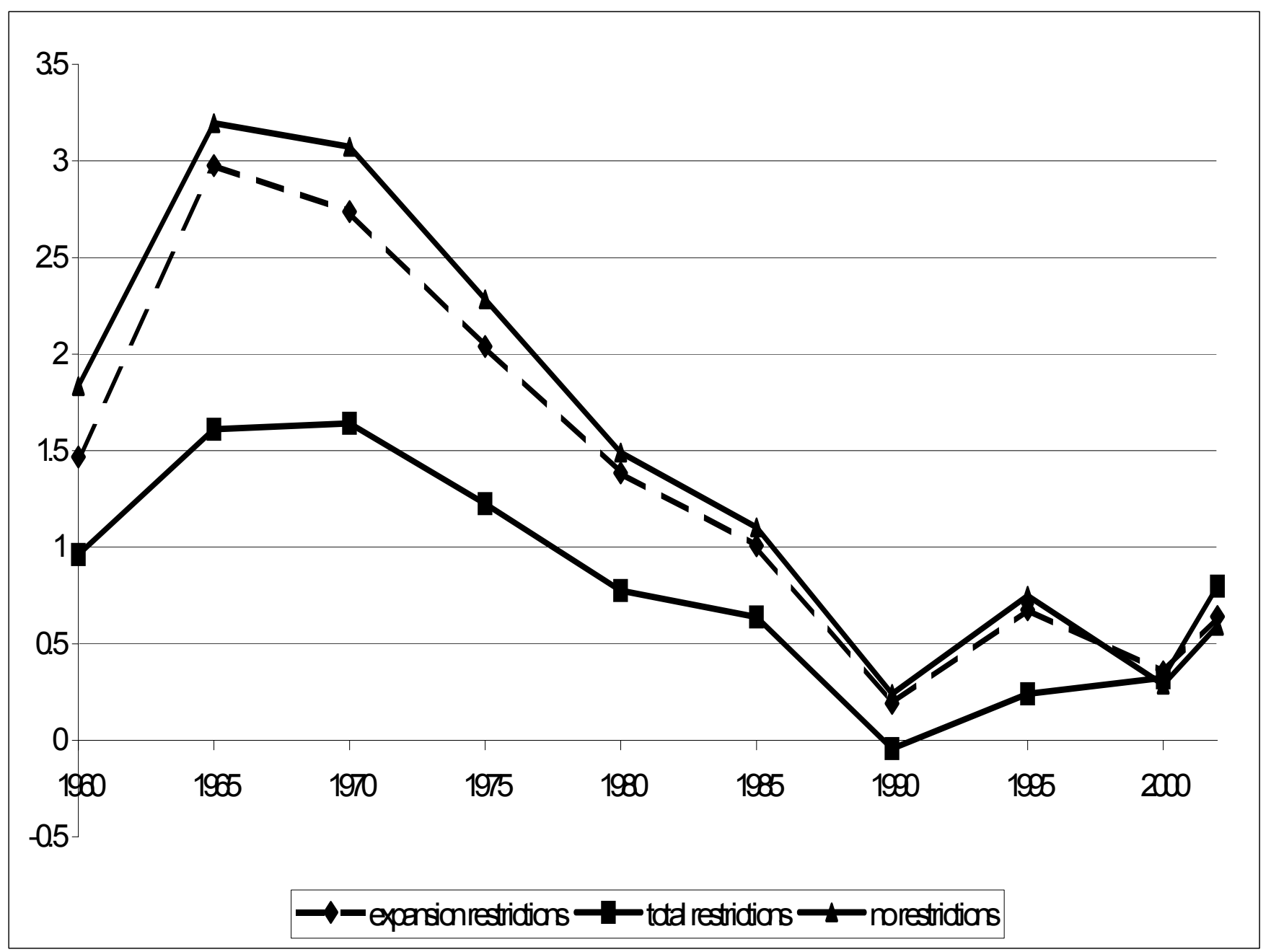

Source: See table 4. 
Figure 2: Net Migration Rate by regions (1960-2002)

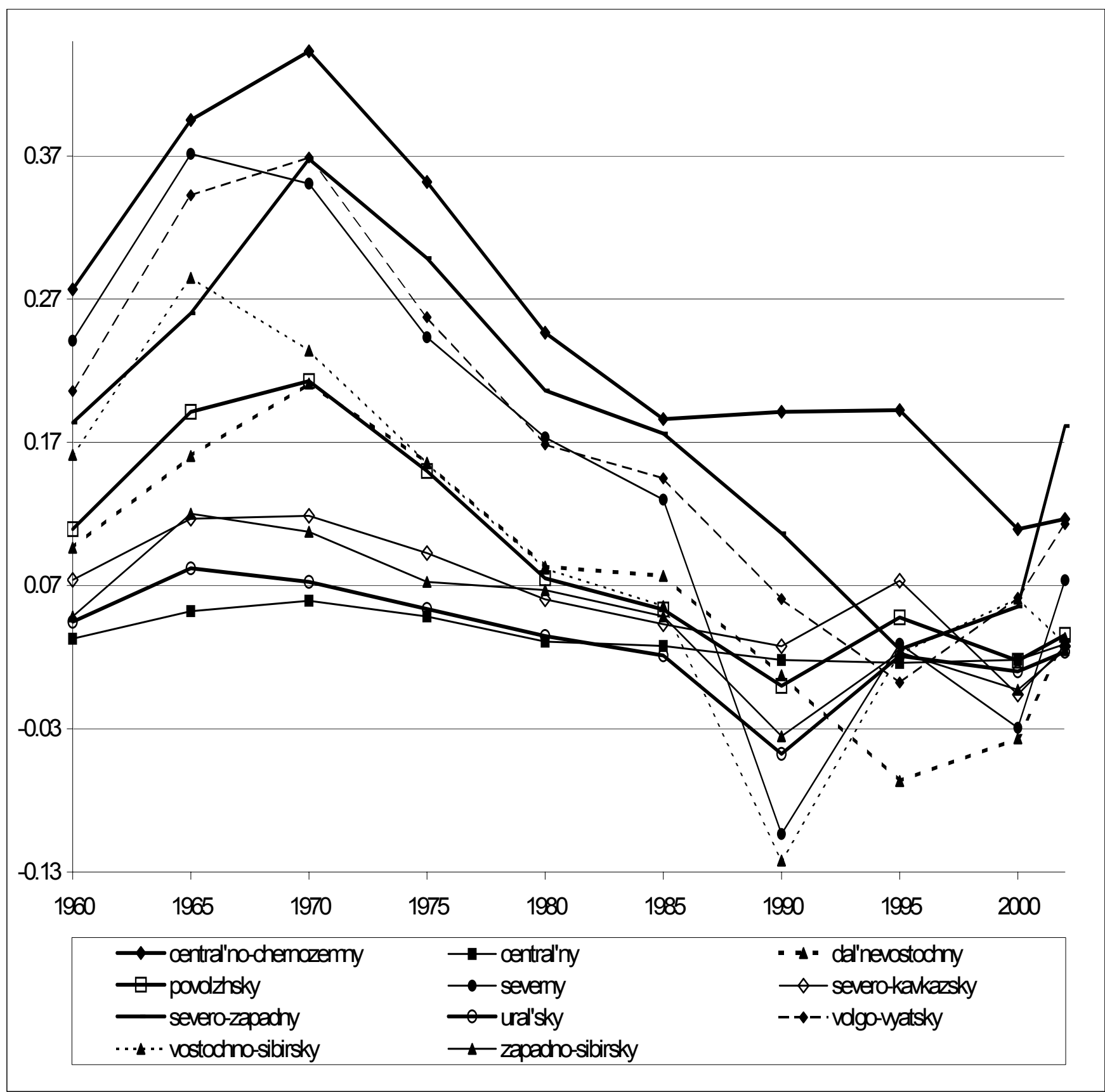

Source: Table 4.

Note: numbers may differ from Table 4 because we use average NMR for each region, not weighted NMR. 


\section{DAVIDSON INSTITUTE WORKING PAPER SERIES - Most Recent Papers}

The entire Working Paper Series may be downloaded free of charge at: www.wdi.bus.umich.edu

CURRENT AS OF 5/12/04

\begin{tabular}{|c|c|c|}
\hline Publication & Authors & Date \\
\hline $\begin{array}{l}\text { No. 697: Russian Cities in Transition: The Impact of Market Forces in } \\
\text { the 1990s }\end{array}$ & Ira N. Gang and Robert C. Stuart & May 2004 \\
\hline $\begin{array}{l}\text { No. 696: Firm Ownership and Internal Labor Practices in a Transition } \\
\text { Economy: An Exploration of Worker Skill Acquisition in Vietnam }\end{array}$ & Jed Friedman & May 2004 \\
\hline No. 695: The Unanticipated Effects of Insider Trading Regulation & $\begin{array}{l}\text { Art A. Durnev and Amrita S. } \\
\text { Nain }\end{array}$ & May 2004 \\
\hline $\begin{array}{l}\text { No. 694: Volatile Interest Rates, Volatile Crime Rates: A New } \\
\text { Argument for Interest Rate Smoothing }\end{array}$ & Garett Jones and Ali M. Kutan & May 2004 \\
\hline $\begin{array}{l}\text { No. } 693 \text { Money Market Liquidity under Currency Board - Empirical } \\
\text { Investigations for Bulgaria }\end{array}$ & $\begin{array}{l}\text { Petar Chobanov and Nikolay } \\
\text { Nenovsky }\end{array}$ & May 2004 \\
\hline $\begin{array}{l}\text { No. 692: Credibility and Adjustment: Gold Standards Versus Currency } \\
\text { Boards }\end{array}$ & $\begin{array}{l}\text { Jean Baptiste Desquilbet and } \\
\text { Nikolay Nenovsky } \\
\end{array}$ & May 2004 \\
\hline $\begin{array}{l}\text { No. 691: Impact of Cross-listing on Local Stock Returns: Case of } \\
\text { Russian ADRs }\end{array}$ & Elena Smirnova & May 2004 \\
\hline $\begin{array}{l}\text { No. 690: Executive Compensation, Firm Performance, and State } \\
\text { Ownership in China:Evidence from New Panel Data }\end{array}$ & Cheryl Long & May 2004 \\
\hline $\begin{array}{l}\text { No. 689: Diverging Paths: Transition in the Presence of the Informal } \\
\text { Sector }\end{array}$ & Max & May 2004 \\
\hline $\begin{array}{l}\text { No. 688: What Causes Bank Asset Substitution in Kazakhstan? } \\
\text { Explaining Currency Substitution in a Transition Economy }\end{array}$ & Sharon Eicher & May 2004 \\
\hline $\begin{array}{l}\text { No. 687: Financial Sector Returns and Creditor Moral Hazard: Evidence } \\
\text { from Indonesia, Korea and Thailand }\end{array}$ & $\begin{array}{l}\text { Ayse Y. Evrensel and Ali M. } \\
\text { Kutan }\end{array}$ & May 2004 \\
\hline $\begin{array}{l}\text { xchange Rates of the World Leading } \\
\text { of a Spatial Competition Model }\end{array}$ & $\begin{array}{l}\text { Dirk Engelmann, Jan Hanousek } \\
\text { and Evzen Kocenda }\end{array}$ & 2004 \\
\hline Spinoffs, Privatization, and Performance in & $\begin{array}{l}\text { Evzen Kocenda and } \\
\text { kf }\end{array}$ & May 2004 \\
\hline $\begin{array}{l}\text { CPI Bias and Real Living Standards in Russia During the } \\
\text { on }\end{array}$ & $\begin{array}{l}\text { John Gibson, Steven Stillman and } \\
\text { Trinh Le }\end{array}$ & May 2004 \\
\hline $\begin{array}{l}\text { No. 683: Mission Implausible III: Measuring the Informal Sector in a } \\
\text { Transition Economy using Macro Methods }\end{array}$ & Jan Hanousek and Filip Palda & May 2004 \\
\hline $\begin{array}{l}\text { No. 682: The Other Side of the Moon: The Data Problem in Analyzing } \\
\text { Growth Determinants }\end{array}$ & $\begin{array}{l}\text {, Dana Hajkova and } \\
\text { ler }\end{array}$ & May 2004 \\
\hline $\begin{array}{l}\text { No. 681: Consumers' Opinion of Inflation Bias Due to Quality } \\
\text { Improvements }\end{array}$ & $\begin{array}{l}\text { Jan Hanousek and Randall K. } \\
\text { Filer }\end{array}$ & May 2004 \\
\hline $\begin{array}{l}\text { No. 680: IMF-Related Announcements, Fundamentals, and Creditor } \\
\text { Moral Hazard: A Case Study of Indonesia }\end{array}$ & $\begin{array}{l}\text { Ayşe Y. Evrensel and Ali M. } \\
\text { Kutan }\end{array}$ & May 2004 \\
\hline No. 679: Privatization Matters: Bank Efficiency in Transition Countries & $\begin{array}{l}\text { John P. Bonin, Iftekhar Hasan and } \\
\text { Paul Wachtel } \\
\end{array}$ & Apr. 2004 \\
\hline $\begin{array}{l}\text { No. 678: Does Market Liberalisation Reduce Gender Discrimination? } \\
\text { Econometric Evidence from Hungary, 1986-1998 }\end{array}$ & $\begin{array}{l}\text { Dean Jolliffe and Nauro F. } \\
\text { Campos }\end{array}$ & Apr. 2004 \\
\hline $\begin{array}{l}\text { No. 677: Governance and Performance of Microfinance Institutions in } \\
\text { Central And Eastern Europe and the Newly Independent States }\end{array}$ & Valentina Hartarska & Apr. 2004 \\
\hline $\begin{array}{l}\text { No. 676: Equilibrium Exchange Rates in the Transition: The Tradable } \\
\text { Price-Based Real Appreciation and Estimation Uncertainty }\end{array}$ & $\begin{array}{l}\text { Balázs Égert and Kirsten } \\
\text { Lommatzsch }\end{array}$ & Apr. 2004 \\
\hline $\begin{array}{l}\text { No. 675: Productivity growth and the real appreciation of the accession } \\
\text { countries' currencies }\end{array}$ & $\begin{array}{l}\text { Kirsten Lommatzsch and Silke } \\
\text { Tober }\end{array}$ & Apr. 2004 \\
\hline $\begin{array}{l}\text { No. 674: Exchange Rate Policy and Inflation in Acceding Countries: } \\
\text { The Role of Pass-through }\end{array}$ & $\begin{array}{l}\text { Fabrizio Coricelli, Boštjan Jazbec } \\
\text { and Igor Masten }\end{array}$ & Apr. 2004 \\
\hline No. 673: Is Kazakhstan a Market Economy Yet? Getting warmer.... & Sharon Eicher & Apr. 2004 \\
\hline $\begin{array}{l}\text { No. 672: Financial Institutions and The Wealth of Nations: Tales of } \\
\text { Development }\end{array}$ & Jian Tong and Chenggang $\mathrm{Xu}$ & Apr. 2004 \\
\hline $\begin{array}{l}\text { No. 671: Interest Rate Pass-Through in EU Acceding Countries: The } \\
\text { Case of the Czech Republic, Hungary and Poland }\end{array}$ & $\begin{array}{l}\text { Jesús Crespo Cuaresma, Balázs } \\
\text { Égert, and Thomas Reininger }\end{array}$ & Mar. 2004 \\
\hline
\end{tabular}

